\title{
ASIAN STUDIES AT HAWAII
}

The Publications Committee of the Asian Studies Program will consider all manuscripts for inclusion in the series, but primary consideration will be given to the research results of graduate students and faculty at the University of Hawaii. The series includes monographs, occasional papers, translations with commentaries, and research aids.

Orders for Asian Studies at Hawaii publications should be directed to The University Press of Hawaii, 535 Ward Avenue, Honolulu, Hawaii 96814. Present standing orders will continue to be filled without special notification. 
Asian Studies at Hawaii, No. 14

POLITICAL CHANGE IN THE PHILIPPINES

Studies of Local Politics Preceding Martial Law

\section{Edited}

by

Benedict J. Kerkvliet

Asian Studies Program

University of Hawaii

The University press of Hawaii 
The Asian Studies Program of the University of Hawaii offers multidisciplinary course work leading to the bachelor's and master's degrees in East Asian, Southeast Asian, and South Asian Studies. In addition, it encourages research and scholarly projects related to Asia. Many departments of the University of Hawaii award advanced degrees for studies dealing with Asia.

Copyright (C) 1974 by The University Press of Hawaii All rights reserved Manufactured in the United States of America

Library of Congress Cataloging in Publication Data Main entry under titie: Political change in the Philippines.

(Asian studies at Hawaii ; no. 14)

Based primarily on essays presented at the annual Association of Asian Studies meeting in New York, Mar. 1972 and a regional meeting of AAS, Nov., 1972.

1. Local government--Philippine Islands-Addresses, essays, lectures. I. Kerkvliet, Benedict J., ed. II. Series. DS3.A2A82 no. 14 LJ S7302 320.9'599'04 74-79007 ISBN $0-8248-0343-4$ 